\title{
Pay-for-Performance Systems in State Government
}

\section{Perceptions of State Agency Personnel Managers*}

\author{
J. Edward Kellough, University of Georgia \\ Sally Coleman Selden, University of Oklahoma
}

\begin{abstract}
Pay for performance has been a widely used method of compensation in the public sector since the early 1980s, but a growing body of research has indicated that numerous problems can be associated with the application of performance-based compensation systems. In late 1993, the federal government, after years of difficulty experienced with its merit pay program, took a significant step back from pay for performance through passage of the Performance Management and Recognition System Termination Act. This research seeks to determine whether state governments are becoming similarly disenchanted with pay for performance. To gain insight into this question, a survey was administered to a nationwide random sample of state agency personnel management executives. Results indicate that pay for performance remains as popular as ever in state government, and that nearly all of the systems in the states utilize merit pay despite difficulties often associated with that approach to pay for performance.
\end{abstract}

$\tau_{\mathrm{v}}^{\mathrm{n}}$ n the late 1970 s and early 1980 s payfor-performance systems were widely viewed as important and innovative mechanisms for enhancing public employee morale and productivity. The basic argument for these compensation structures, i.e., the notion that compensation should be made proportional to performance, is often appealing, and the general features of pay for performance are by now well known-excellent performers are to receive higher pay increases while average and poorer performers earn lower adjustments to pay. The federal government's experience with this concept dates largely from the Civil Service Reform Act of 1978. Shortly after the federal program was initiated, state governments also began experi- menting with pay for performance (Argyle, 1982), and by the mid-1980s more than twenty states had systems in place where employees with higher performance ratings received higher compensation than those with lower ratings (Lawther et al., 1989; U.S. General Accounting Office, 1990).

There are a variety of approaches to the implementation of pay for performance. The most common approach, and the approach that has received the most attention in the professional literature, consists of individualized performance-based wage incentives, usually known as merit pay. Merit pay distributes awards for superior performance as permanent increases to an individual's base salary. As a result, awards distributed will continue to impact an 
individual's salary long after the performance warranting recognition has faded into the past. An alternative approach is to give the award as a one time bonus payment separate from the individual's base pay. Under a system of bonuses, superior performance is rewarded only for the period during which it has been observed. A third variant distributes awards (merit pay or bonuses) on the basis of group rather than individual effort because of difficulties sometimes associated with individualized performance appraisals. Group-based incentive systems, known as gain sharing or variable pay, reward an entire organizational unit or work group for exceptional performance in meeting organizational goals.

Despite the popularity of pay for performance in the public sector, by the late 1980 s and early 1990s the effectiveness of this compensation strategy was called into question. Research on the topic had generated evidence that pay-for-performance systems, particularly merit pay plans, could often be problematic. Numerous scholars documented difficulties associated with merit pay, including problems connected with performance evaluation, the apparent re. luctance of government to adequately fund the systems, and the fact that merit pay often led to dysfunctional competition among employees (Ingraham, 1993a; Lovrich, 1987; Milkovich and Wigdor, 1991; Pearce \& Perry 1983; Perry, 1988. 89; Perry \& Pearce, 1985). As evidence of problems associated with merit pay systems grew, the federal government retreated from the concept by terminating the Performance Management and Recognition System (the federal merit pay system) in 1993 (U.S. Statutes at Large, 1993). Employees who had been covered by the merit pay program were returned to the generai schedule pay structure. In effect, the federal service was required to abandon the concept of individualized wage incentives added to base pay. Under current regulations, federal agencies may continue incentive programs, including cash awards, but wage incentives may only be distributed as one-time bonuses (U.S. Federal Register, 1995) ${ }^{1}$

Have state governments similarly backed away from the concept of merit-pay? This is a central question to be addressed in the present study. While much of the research that has highlighted the questionable utility of merit pay has focused on the federal experience, there is evidence that states have also confronted problems (Ingraham, 1993a, 1993b; Lovrich, 1987; Nachmias \& Moderacki, 1982). It has been suggested, however, that there may be a variety of political and symbolic reasons for jurisdictions to continue the use of merit pay even though it may not always be particularly effective instrumentally (Fox \& Miller, 1992; Kellough \& Lu, 1993; Perry, 198889). This research seeks to discover the extent to which pay-for-performance systems remain in place in state government, whether merit pay is the dominant approach where pay for performance is used, and whether state executives at the forefront of public personnel management practice perceive pay for performance as a viable approach to compensation administration. Do public personnel managers who may be responsible for the administration of pay-for-performance systems in state organizations see the same problems that have been identified in the literature?

\section{Methodology}

In order to develop an understanding of the current use of pay-for-performance systems by state governments, a questionnaire 
was mailed in 1994 to a nationwide random sample of 350 personnel managers located in state agencies. Managers from all fifty states were included in the sample. The questionnaire sought information regarding the utilization of pay for performance, the type of system used, and perceptions of the advantages of pay for performance as well as any disadvantages or problems that might have been experienced.

Respondents were guaranteed anonymity. A postcard with return postage was included in the mailing with the survey instrument and cover letter as Dillman (1978) suggests, and respondents were asked to return the postcard separately to indicate that they had returned the questionnaire. In this way, respondents and nonrespondents could be tracked, but there was no way to associate respondents with returned questionnaires. To boost the response rate, a follow-up mailing of postcard reminders was sent to nonrespondents approximately four weeks after the original mailing. Four weeks later, a second follow-up reminder with a copy of the questionnaire was sent to those who had still not responded. One hundred and eighty-nine completed surveys were returned producing a response rate of 54 percent.

\section{Results}

Responses were received from personnel managers from all fifty states. Approximately 46 percent of the respondents were women and 54 percent were men. All major racial/ethnic groups were represented, with 79.9 percent of respondents being white, 12.8 percent African American, 3.9 percent Hispanic, 1.7 percent Asian, and 1.7 percent Native American. Respondents ranged in age from 32 years to 68 with a mean of 47 . In terms of educational attainment, nearly 44 percent held graduate degrees, with the MPA and MA being the most frequently held credentials. An additional 43 percent of respondents held bachelor degrees. Thirteen percent possessed only a high school education.

More than 75 percent of the respondents had 10 or more years of work experience in personnel management - a majority having worked exclusively in the public sector. Sixty-eight percent of respondents were in positions covered by classified civil service systems while 32 percent were political appointees. Position titles included "Direc. tor, Personnel Division," "Human Resource Manager," "Personnel Manager," "Chief, Personnel Programs Division," "Deputy Assistant Director of Personnel," and other related titles. Responsibilities of the respondents covered the full range of personnel management tasks including supervision of job analysis, classification, compensation, performance management, training, and planning.

\section{Are State Governments Retreating from Pay-for-Performance?}

Managers from 30 different states, representing approximately 34 percent of all respondents, indicated that the state agency, bureau, or department in which they were employed had a pay-for-performance system in place at the time of the survey. Coupled with findings from earlier research indicating that considerably fewer states had pay for performance in the $1980 \mathrm{~s}$, this finding suggests that state governments are not moving away from compensationbased incentive structures. Of course, responses were not uniform in all of the 30 states where use was reported. In most of the states with pay for performance, there were some personnel managers who indicated that their particular organization did not use such a system. Earlier research 
uncovered similar mixed patcens of utilization. Apparently the number of organizations and employees covered by state payfor-performance systems varies to a significant degree within each state. Lawther et al. (1989), for example, found 22 states using pay for performance in 1987 , but the number of employees covered differed from state to state. Similarly, the U.S. General Accounting Office (GAO) found that payfor-performance systems were in place in 23 states in 1989, but there was considerable variation across states in the number and types of employees included in the systems (U.S. General Accounting Office, 1990). As a result, an indication that the concept has been used recently by organizations in as many as 30 different states provides evidence that the "general movement toward pay for performance" noted by the GAO in 1990 has continued despite a growing body of research suggesting that such systems can be fraught with difficulty. ${ }^{2}$

\section{Is Merit Pay Still the Dominant Approach for Linking Pay and Performance?}

More than ninety percent of the respondents whose organizations utilized pay for performance reported that their system allocated awards based on individualized performance evaluations and that awards were distributed as permanent increases in the individual's base pay. Thus, according to survey results, merit pay remains the most frequently occurring manifestation of pay for performance in the states despite the fact that it is perhaps the most problematic approach to pay for performance. By comparison, only 52 percent of the respondents reported that their organizations used individualized bonuses and 11 percent reported using group-based incentives. Some organizations using merit pay, however, were also using bonuses or group incentives. In fact, 42 percent reported using merit pay along with other approaches, while 48.3 percent indicated that merit pay, i.e., individualized awards added to base pay, was the only approach utilized. A relatively small proportion of state personnel managers $(9.7$ percent) reported that their agency used bonuses or group-based approaches exclusively.

\section{Is Pay-for-Performance Perceived as an Effective Tool for Motivating Employees and Increasing Productivity?}

The logic underlying pay for performance is that the system will increase employee motivation and productivity by increasing the likelihood that superior performance will lead to monetary benefits. Personnel managers from organizations using pay for performance were asked to rate the overall effectiveness of the approach. As Figure 1 shows, a majority (56.5 percent) agreed that pay for performance is an effective tool for motivating employees and increasing productivity. Specifically, 6.5 percent strongly agreed that pay for performance is effective, 16.1 percent agreed, and 33.9 percent agreed slightly. By contrast, only approximately 26 percent of the respondents disagreed with the notion that pay for performance is effective and 18 percent were unsure. These findings reveal a somewhat more positive impression of pay for performance among state government officials than that reported in earlier work by Ingraham (1993b) and, as a result, provide further evidence of the continuing appeal of pay for performance in the states. Ingraham interviewed 20 directors of state central personnel agencies and found that only 40 percent rated their state's pay-forperformance system as "somewhat effective" or "effective."

In order to better understand general 
personnel managers' attitudes toward pay for performance, the relationship between managers' perceptions of effectiveness depicted in Figure 1 and a number of individual and organizational variables possibly associated with those perceptions was ex- amined. Multiple regression analysis produced results depicted in Table 1. Four of the eight variables included in the model bear a statistically significant relationship to perceptions of pay for performance as an effective tool for motivating employees and

Figure 1. Perception of the Effectiveness of Pay for Performance

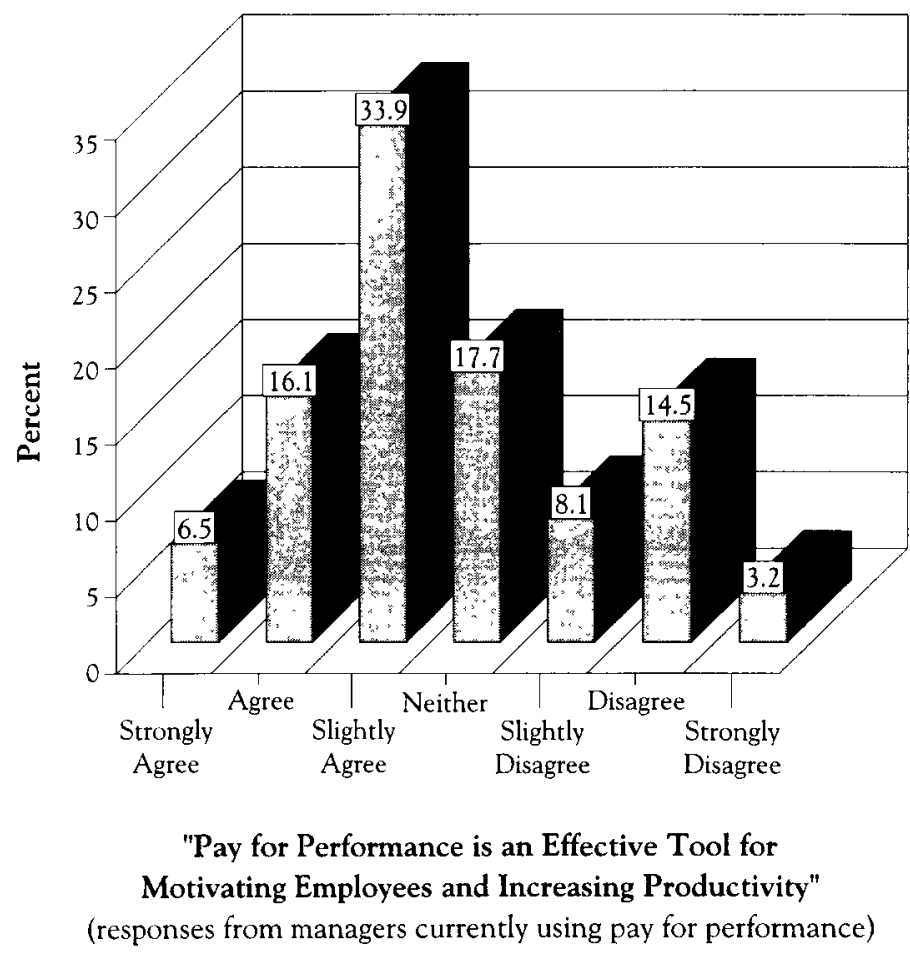

Pay for Performance Systems - Kellough \& Selden 9 
increasing productivity." The amount of experience a respondent has in personnel management, for example, is negatively associated with attitudes toward pay for performance. That is, as years of experience in personnel management increase, the perception of pay for performance as an effective strategy declines. Respondents with more experience are more likely to be skeptical of pay for performance. One explanation for this result may be that those managers with more experience are more attuned to the many problems so often associated with pay-for-performance systems, especially merit pay plans.

A second variable that is significantly associated with respondents' perceptions is whether on not the respondent is a political appointee. While a majority of the personnel management executives surveyed in organizations utilizing pay for performance were in classified civil service positions, a substantial proportion ( 32 percent) were political appointees. As indicated in Table 1 , these respondents were much more likely to have a positive perception of pay for performance. This outcome may be due to the political and symbolic impact of this approach to compensation. Pay for performance may have important political value as a symbol of the government's effort to promote bureaucratic productivity (Kellough \& Lu 1993; Perry 1988-89).

It is also interesting to observe that respondents with experience in the private sector are significantly more negative in their assessments of pay for performance than are respondents who have worked exclusively in the public sector. At first glance, this result may seem counter-intuitive since advocates of pay for performance often cite successful experience in the private sector as a justification for adoption in government, but it has been well docu- mented that applications in the private sector have encountered their own share of problems (Ingraham, 1993a). Furthermore, as Ingraham (1993a) has suggested, the relative lack of management flexibility and control characteristic of the public sector may be inconsistent with innovations such as pay for performance. It may be the case that managers who have experience in the private sector are more sensitive to difficulties peculiar to the use of pay for performance in public organizations.

A final variable significantly associated with respondents' perceptions of pay for performance has to do with the coverage of the system in place in the respondent's organization. More specifically, respondents from organizations with systems that cover both management and nonmanagement employees (as opposed to management alone) are significantly less inclined to consider pay for performance an effective tool than are respondents whose systems are limited to management. In other words, as coverage of the system increases to include both management and nonmanagement employees, perceptions of the effectiveness of pay for performance go down. This outcome suggests that additional problems may be encountered when pay for performance is applied to those in nonmanagerial positions.

Other variables in the model fail to demonstrate a statistically significant relationship with respondents' perceptions of pay for performance, although the direction of the relationship revealed is consistent with what was expected. The respondent's level of education, the size of the respondent's organization, the method of pay for performance utilized (i.e., merit pay exclusively or an alternative approach using bonus or group incentives either exclusively or in combination with merit pay), and the num- 
ber of years that pay for performance has been in place are all insignificant in their impact on perceptions of the effectiveness of pay for performance (see Table 1). Of these results, the finding that the method of pay for performance utilized has no significant impact on perceptions of effectiveness is perhaps most interesting. This result suggests that, despite the potential problems associated with merit pay, respondents with systems that rely exclusively on that approach are not significantly more negative in their perceptions of pay for performance than are those who have a merit pay system combined with other approaches or have used other approaches exclusively. ${ }^{4}$

\section{What Positive Outcomes Are Associated with Merit Pay?}

Because merit pay has been such a prominent approach to pay for performance, respondents whose organizations utilized merit pay were asked whether they agree or disagree that merit pay has led to certain specific benefits. Results from this portion of the questionnaire are displayed in Table $2 .{ }^{5}$ Among the most frequently cited benefits are those that address the clarification of organizational expectations and standards. For example, 66 percent of the respondents agreed that merit pay has led to the clarification of individual roles and responsibilities. Almost 56 percent indicated that the relationship between monetary rewards and performance was clarified by the implementation of merit pay. In addition, more than 54 percent agreed that merit pay facilitated the clarification of performance standards and measures.

By contrast, relatively modest numbers of respondents agreed with statements sug. gesting that merit pay succeeded in achieving more instrumental objectives in their

Table 1. Impact of Selected Individual and Organizational Variables on Perceptions of Pay for Performance as an Effective Tool for Motivating Employees and Increasing Productivity

Independent Variables $\quad B \quad$ Standard Error

$\begin{array}{lrc}\text { Years in personnel management } & -0.108 & .048^{* *} \\ \text { Political appontee } & 1.448 & .563^{* * *} \\ \text { Private sectur expertence } & -1.732 & 1.141^{*} \\ \text { Level of education } & -0.230 & .235 \\ \text { Size of organization } & -0.007 & .008 \\ \text { Method of pay for performance } & -0.074 & .098 \\ \text { Years pay for performance used } & -0.005 & .038 \\ \text { Coverage of system } & -2.078 & .681^{* *}\end{array}$


unganizations. Only 39 percent, for example, agreed that it actually increased employee motivation or productivity. Approximately 37 percent found that it increased employee satisfaction. While these benefits are often cited in support of pay for performance in general, the relatively small proportions of respondents seeing these outcomes associated with merit pay suggest that this approach to pay-forperformance may not always be a reliable mechanism for enhancing employee motivation and satisfaction.

It is sometimes argued that merit pay will help organizations attract and retain top caliber employees (Ingraham, 1993a; Milkovich \& Wigdor, 1991). Results from the current survey, however, do not suggest that state governments frequently realize these benefits. In fact, only 22 percent of the respondents with merit pay in their organizations indicate that it has improved recruiting, and only 27 percent agree that it has led to decreased employee turnover in their organizations. ${ }^{7}$ Other proposed benefits fare no better. Only approximately 15 percent of respondents believe that political executives have more control over career bureaucrats under a merit-pay plan or that merit pay has reduced labor costs.

The fact that the clarification of performance standards, individual roles and responsibilities, and the relationship between monetary rewards and performance are the most commonly observed benefits of merit pay is intriguing. While these objectives may be viewed by some as secondary, Ingraham (1993b) found that improved manager-employee communication was the most frequently mentioned expectation for pay for performance among directors of state personnel agencies. Findings here are similar in that the "clarification" cited by survey respondents is most likely achieved through better communications between individuals and their supervisors.

\section{What Negative Outcomes Are Associated with Merit Pay?}

As indicated earlier, research on the impact of pay for performance has frequently reported a number of negative effects associated with its application. This is especially true of evaluations of merit-pay plans (Daley, 1987; Pearce \& Perry, 1983; Pearce, Stevenson, \& Perry, 1985). Drawing on previous studies, respondents were asked to assess the extent to which merit pay produced specific negative impacts (see Table 3). Respondents voiced the greatest concern about the propensity of such systems to generate organizational red tape. More specifically, over 67 percent agreed that merit pay has increased demands on supervisors' time, and more than 64 percent agree that it has led to the need for extensive documentation and paperwork.

Of the other problems listed in Table 3, several are of such a fundamental nature that the perceived negative outcomes may hint at critical problems associated with the concept. For example, nearly 63 percent of the personnel executives in organizations with merit-pay systems agreed with the statement that merit pay has reduced employee confidence in supervisory objectivity and precision, and 56.9 percent perceive that their system fails to consistently discriminate among different levels of employee performance. In addition, over 47 percent of the respondents perceived that performance awards are not distributed fairly. As noted by Milkovich and Wigdor (1991), an individual's perception of procedural fairness may be linked subsequently to his or her level of job satisfaction. That being the case, a poorly structured merit- 
pay system may actually undermine employee job satisfaction and motivation to perform.

\section{Differentiating Among Perceptions of} Effectiveness and Ineffectiveness of Pay for Performance

Respondents reporting the utilization of merit pay in their organizations were divided into two groups: one that perceived pay for performance as at least slightly effective and another that at least slightly disagreed with the statement that pay for performance was effective. Average (mean) responses of these two groups on the issues specific to merit pay displayed in Tables 2 and 3 were then calculated and compared in order to determine whether perceptions of advantages and disadvantages of merit pay help to differentiate between the groups and which particular issues appear to be most salient. ${ }^{8}$ For several of the items there were pronounced differences between the groups as expected. The clearest example of such a pattern occurred with respect to the statement that merit pay increased motivation among employees. As Table 4 shows, respondents differed significantly on this issue, with those who considered pay for performance ineffective disagreeing with the statement and those who found pay for performance to be effective more likely to agree that merit pay worked to motivate employees. Interesting differences in response patterns are also found on the question of whether the use of merit pay has led to a lack of confidence among employees in supervisory objectivity and precision in rating employee performance. Both groups were inclined to agree that employee con-

Table 2. Positive Outcomes Associated with Merit Pay

\begin{tabular}{|c|c|c|c|}
\hline Merit Pay has led to: & Disagree & Neither & Agree \\
\hline Increased motivation among employees & $39.0 \%$ & $22.0 \%$ & $39.0 \%$ \\
\hline Increased employee satisfaction & 28.8 & 33.9 & 37.3 \\
\hline Increased employee productivity & 27.1 & 33.9 & 39.0 \\
\hline $\begin{array}{l}\text { Improvement of management/supervisory } \\
\text { control over subordinates }\end{array}$ & 32.2 & 32.2 & 35.6 \\
\hline $\begin{array}{l}\text { Improvement of political executive control } \\
\text { over career bureaucrats }\end{array}$ & 44.0 & 40.7 & 15.3 \\
\hline $\begin{array}{l}\text { Clarification of performance standards and } \\
\text { measures }\end{array}$ & 23.8 & 22.0 & 54.2 \\
\hline $\begin{array}{l}\text { Clarification of individual roles and } \\
\text { responsibilities }\end{array}$ & 17.0 & 16.9 & 66.1 \\
\hline $\begin{array}{l}\text { Clarification of the relationship between } \\
\text { monetary rewards and performance }\end{array}$ & 25.5 & 18.6 & 55.9 \\
\hline Reduced labor costs & 49.1 & 35.6 & 15.3 \\
\hline Improved recruitment & 42.4 & 35.6 & 22.0 \\
\hline Lower turnover & 39.0 & 33.9 & 27.1 \\
\hline Greater accountability to the public & 42.4 & 35.6 & 22.0 \\
\hline
\end{tabular}


fidence in supervicory objectivity and precision declined with merit pay, but those who had previously rated pay for performance as ineffective agreed with this observation most strongly.

Overall, significant differences existed on all but seven of the items listed in Table 4. Thus, most items are important in determining perceptions of pay for performance. Among the items for which there are no significant differences, however, one of the more interesting is the issue of whether merit pay clarified the relationship between monetary rewards and performance. Average responses indicate that those who saw pay for performance as effective were likely to agree (at least slightly) with this proposition and those finding pay for performance ineffective were generally undecided, but the difference between the two groups was not statistically significant. Other items for which there was relatively little disayleement included the issues of whether merit pay improved management and supervisory control over subordinates and whether it reduced labor costs, led to greater accountability to the public, led to increased demands on supervisors time, increased paperwork, and resulted ultimately in employees feeling that they were inadequately compensated. Average responses on all of these questions are reported in Table 4.

\section{Factors Making the Implementation of Merit Pay Difficult}

It is sometimes the case that problems associated with merit pay can be traced to the lack of proper implementation of the concept (Daley, 1987; Pearce \& Perry, 1983; Pearce, Stevenson, \& Perry, 1985). In an effort to discern the extent to which state personnel executives experienced spe. cific implementation problems identified in

\section{Table 3. Negative Outcomes Associated with Merit Pay}

\begin{tabular}{|c|c|c|c|}
\hline Implementing merit pay has produced the following: & Disagree & Neither & Agree \\
\hline Employee conflict and competition over ratings and awards & $31.0 \%$ & $25.9 \%$ & $43.1 \%$ \\
\hline $\begin{array}{l}\text { Lack of employee confidence in supervisory objectivity and } \\
\text { and precision }\end{array}$ & 20.4 & 16.9 & 62.7 \\
\hline $\begin{array}{l}\text { Failure to consistently discriminate among different levels of } \\
\text { employee performance }\end{array}$ & 17.2 & 25.9 & 56.9 \\
\hline Employee distrust of the performance appraisal system & 25.5 & 20.3 & 54.2 \\
\hline $\begin{array}{l}\text { Employee reluctance to perform tasks not specifically } \\
\text { included in appraisal documents }\end{array}$ & 39.0 & 25.4 & 35.6 \\
\hline Performances awards are not distributed fairly & 30.5 & 22.0 & 47.5 \\
\hline $\begin{array}{l}\text { Employees feel that they are inadequately compensated } \\
\text { for their performance }\end{array}$ & 22.1 & 20.3 & 57.6 \\
\hline Increased demands on supervisors' time & 22.0 & 10.2 & 67.8 \\
\hline Extensive documentation and paperwork & 23.7 & 11.9 & 64.4 \\
\hline Legal challenges and appeals of performance ratings & 35.6 & 13.6 & 50.8 \\
\hline
\end{tabular}

14 Rev. of Public Personnel Administration - Winter 1997 
other studies, those surveyed were asked to respond to potential difficulties listed in Table 5. The most commonly experienced problems appear to be those related to adequate funding of the systems. For example, over 70 percent of state personnel executives agreed that both a lack of sufficient funding and fixed pay-for-performance budgets made implementation difficult. In addition to problems with funding, a major-

\section{Table 4. Difference of Means on Outcomes Associated with Merit Pay}

\begin{tabular}{|c|c|c|c|c|}
\hline \multirow[b]{2}{*}{ Impacts of merit pay } & \multicolumn{4}{|c|}{ Group Means } \\
\hline & Effective & Not Effective & $t$ & Sig. \\
\hline Increased motivation among employees & 3.52 & 5.33 & 4.90 & .000 \\
\hline Increased employee satisfaction & 3.67 & 4.57 & 4.56 & .038 \\
\hline Increased employee productivity & 3.60 & 4.67 & 2.97 & .007 \\
\hline $\begin{array}{l}\text { Improvement of management/supervisory } \\
\text { control over subordinates }\end{array}$ & 3.85 & 4.53 & 1.53 & .140 \\
\hline $\begin{array}{l}\text { Improvement of political executive control over } \\
\text { career bureaucrats }\end{array}$ & 4.27 & 5.60 & 3.36 & .002 \\
\hline $\begin{array}{l}\text { Clarification of performance standards and } \\
\text { measures }\end{array}$ & 3.00 & 3.93 & 1.84 & .080 \\
\hline Clarification of individual roles and responsibilities & 2.76 & 3.80 & 2.05 & .055 \\
\hline $\begin{array}{l}\text { Clarification of the relationship between monetary } \\
\text { rewards and performance }\end{array}$ & 3.33 & 4.00 & 1.22 & .235 \\
\hline Reduced labor costs & 4.85 & 5.07 & .48 & .632 \\
\hline Improved recruitment & 4.27 & 5.13 & 1.87 & .072 \\
\hline Lower turnover & 4.09 & 5.20 & 2.65 & .013 \\
\hline Greater accountability to the public & 4.36 & 5.07 & 1.35 & .190 \\
\hline $\begin{array}{l}\text { Employee conflict and competition over ratings } \\
\text { and awards }\end{array}$ & 4.21 & 3.21 & -2.06 & .049 \\
\hline $\begin{array}{l}\text { Lack of employee confidence in supervisory } \\
\text { objectivity and precision }\end{array}$ & 3.97 & 2.57 & -3.38 & .002 \\
\hline $\begin{array}{l}\text { Failure to consistently discriminate among } \\
\text { different levels of employee perfornance }\end{array}$ & 3.85 & 2.29 & -3.88 & .001 \\
\hline Distrust of the performance appraisal system & 3.82 & 2.64 & -2.35 & .028 \\
\hline $\begin{array}{l}\text { Employee reluctance to perform tasks not } \\
\text { specifically included in appraisal documents }\end{array}$ & 4.71 & 3.29 & -3.11 & .005 \\
\hline Performance awards are not distributed fairly & 4.24 & 3.14 & -2.27 & .032 \\
\hline $\begin{array}{l}\text { Employees feel that they are inadequately } \\
\text { compensated for their performance }\end{array}$ & 3.41 & 2.64 & -1.49 & .149 \\
\hline Increased demands on supervisors' time & 3.59 & 2.86 & -1.30 & .209 \\
\hline Extensive documentation and paperwork & 3.44 & 2.79 & -1.09 & .289 \\
\hline $\begin{array}{l}\text { Legal challenges and appeals of performance } \\
\text { ratings }\end{array}$ & 4.47 & 3.14 & -2.51 & .020 \\
\hline
\end{tabular}

Survey responses were scored from 1 (strongly agree) to 7 (strongly disagree). 
ity of the respondents also cxpressed conicern over the ability to develop good performance measures and the ability to apply performance measures consistently. These findings match those of previous research on federal and local jurisdictions and suggest, therefore, that similar implementation problems exist at all levels of government using merit-pay systems (Gabris, 1986; Milkovich \& Wigdor, 1991; Perry, 1986; Perry, Petrakis, \& Miller, 1989;U.S. General Accounting Office, 1990).

\section{Why Does the Concept Survive?}

Why are state governments continuing to use the merit pay approach to pay for performance given that considerable research suggests that it often fails to achieve its objectives and is plagued continually by similar problems across different systems and governmental units? To better understand this issue, respondents were asked to rate the extent to which a number of different factors contributed to the continued use of merit pay in their organizations (see Table 6). One reason agreed upon was that merit pay makes employees responsible for performing high quality work. Over 76 percent agreed with this proposition, although as noted earlier a much smaller proportion of respondents actually believe pay for performance is effective in their organizations and fewer still see merit pay as an effective strategy for motivating employees. It is also the case that nearly 73 percent of the respondents indicated that their organizations continue to use merit pay because a substantial investment had been made in the system. Sixty-three percent of the respondents also thought that their organization continued to utilize merit-pay systems because merit pay has been successfully used in the private sector. Less than a majority (42.4 percent) of the respondents agreed

\section{Table 5. Problems Encountered During Implementation of Merit Pay}

\begin{tabular}{|c|c|c|c|}
\hline $\begin{array}{l}\text { The following factors have presented problems } \\
\text { when implementing merit pay: }\end{array}$ & Disagree & Neither & Agree \\
\hline Lack of adequate funding & $22.0 \%$ & $3.4 \%$ & $74.6 \%$ \\
\hline Fixed pay-for-performance budget & 12.3 & 17.5 & 70.2 \\
\hline Salary ceilings & 23.7 & 11.9 & 64.4 \\
\hline Unable to develop good performance measures & 30.6 & 18.6 & 50.8 \\
\hline $\begin{array}{l}\text { Difficult to get supervisors to apply performance } \\
\text { measures consistently }\end{array}$ & 18.6 & 15.3 & 66.1 \\
\hline $\begin{array}{l}\text { Difficult to link performance and pay because of } \\
\text { performance measures }\end{array}$ & 22.0 & 18.6 & 59.4 \\
\hline $\begin{array}{l}\text { Difficult to link performance and pay because of } \\
\text { small size of the "merit" or "performance-based" } \\
\text { rewards }\end{array}$ & 16.9 & 15.3 & 67.8 \\
\hline Lack of employee support & 37.3 & 33.9 & 28.8 \\
\hline Political constraints & 30.5 & 27.1 & 42.4 \\
\hline Supervisory abuse of discretion & 40.7 & 22.0 & 37.3 \\
\hline
\end{tabular}


that merit pay was continued because it enhances political executives' control over career bureaucrats.

Despite evidence of negative outcomes and implementation difficulties commonly encountered with merit pay, 81 percent of the pay-for-performance users with meritpay systems believe that their organization should not abandon the concept. In an effort to gauge the perceived level of usefulness of pay for performance in general among nonusers, individuals whose organizations had not implemented a pay-forperformance system were asked whether or not they believed it is a potentially useful tool. Approximately 77 percent of those respondents indicated that pay for performance is at least a somewhat potentially useful pay strategy (see Figure 2).

\section{Conclusion}

This research has produced a number of interesting results. First, it does not appear that state governments are backing away from the use of pay for performance. In fact, there is some indication that the utilization of pay for performance is more widespread now than in the 1980 s. Second, pay for performance in the states almost always means the implementation of merit pay. Nearly all pay-for-performance systems in place make use of that strategy, although a number of difficulties are often associated with that approach to pay for performance. Even so, a majority of state personnel managers in organizations with pay for performance report that their system is at least somewhat effective in motivating employees and increasing productivity. When looking at perceptions of effectiveness more closely, it appears that managers with less experience in personnel administration or those whose personnel experience is limited to the public sector, those who are political appointees, and those who have systems covering only managerial employees

Table 6. Factors Contributing to the Continued Use of Merit Pay

\begin{tabular}{|c|c|c|c|}
\hline $\begin{array}{l}\text { To what extent do the following factors } \\
\text { contribute to the continued use of merit pay } \\
\text { in your organization }\end{array}$ & Not at all & Uncertain & $\begin{array}{l}\text { To at leas } \\
\text { some exte }\end{array}$ \\
\hline It is a means of political control of the bureaucracy & $44.1 \%$ & $23.7 \%$ & $32.2 \%$ \\
\hline $\begin{array}{l}\text { It is a symbolic response to public perceptions of } \\
\text { bureaucratic inefficiency and demands of } \\
\text { accountability }\end{array}$ & 21.7 & 20.0 & 58.3 \\
\hline $\begin{array}{l}\text { It makes employees responsible for performing high } \\
\text { quality work }\end{array}$ & 13.6 & 10.2 & 76.2 \\
\hline It enhances supervisors' control over subordinates & 19.0 & 19.0 & 62.0 \\
\hline $\begin{array}{l}\text { It enhances political executives' control over career } \\
\text { bureaucrats }\end{array}$ & 28.8 & 28.8 & 42.4 \\
\hline We have invested substantially in the system & 11.9 & 15.3 & 72.8 \\
\hline It has been successfully used in the private sector & 10.2 & 27.1 & 62.7 \\
\hline
\end{tabular}


are decıdediy more positıve in their assessment of pay for performance.

A question that remains is why, given the common problems experienced, does pay for performance-especially programs that include merit pay-continue to flourish? Part of the explanation may be that alternative "grade and step" approaches where pay increases are distributed almost automatically as rewards for employees' continued service are difficult to reconcile with widely held notions of meritocracy. A large share of state personnel managers, for example, agree with the statement that merıt pay is maintaned in their organizations because it makes employees responsible for performing high quality work. Other explanations are also plausible, however. Almost 73 percent of the personnel managers surveyed suggest that merit pay continues because of substantial past investments in the system. As with numerous other programs, once merit pay is in place, and it has presumably been sold to employees and the public as a desirable reform, it may be difficult for an organization to abandon it. Other reasons for the endurance of merit pay include the belief that it has been

Figure 2. Perceptions of the Potential Usefulness of Pay for Performance

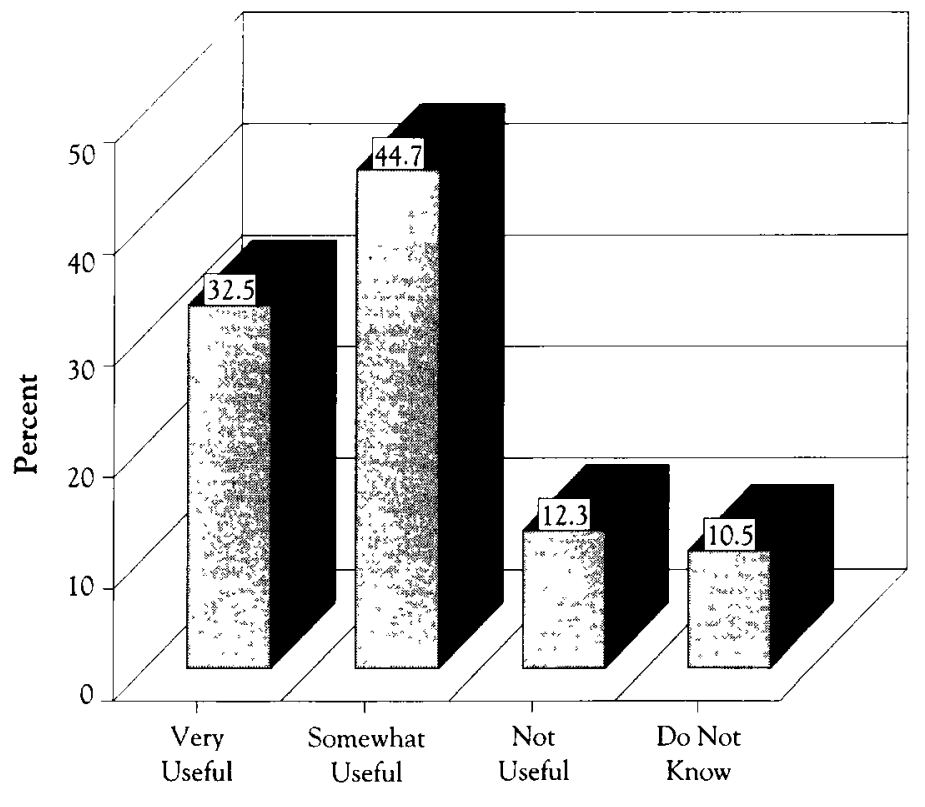

Potential Usefulness of Pay for Performance

(responses from managers who do not currently use pay for performance) 
successful in the private sector and the idea that it enhances supervisors' control over subordinates. A majority of state agency personnel managers also acknowledged that it serves as a symbolic response to public perceptions of bureaucratic inefficiency and demands for accountability.

What does the future hold for pay for performance in state government? It is difficult to know with certainty, but the concept does appear to have a tenacious hold on state policy makers. While efforts to implement pay for performance may be well intended and can certainly be understood, decision makers should give careful consideration to the experiences highlighted here, especially the apparent inability of governments to achieve many of the objectives of pay for performance, the persistent problems encountered during implementation, and the possibility of negative side effects associated with pay-for-performance systems.

\section{Notes}

*This research was made possible by grants from the Carl Vinson Institute of Government and the Office of the Vice President for Research at the University of Georgia. Special thanks go to Richard W. Campbell and Rebecca A. Hill. The authors would also like to thank Jeffrey L. Brudney, Darrell A. Leitner, Bonnie G. Mani, and Hal G. Rainey for valuable comments on an earlier draft of the manuscript.

${ }^{1}$ According to regulations issued by the U. S. Office of Personnel Management, "An agency may grant a cash, honorary, or informal recognition award, or grant time-off without charge to leave or loss of pay" for superior performance by an individual or group (U.S. Federal Register, 1995 , p. 43964). Cash awards, however, are to be "lump-sum payments" only. Quality step increases that have always been part of the General Schedule pay system are permitted, but the required linkage between general increases in base pay and performance that existed under the Performance Management and Recognition System no longer exists.

${ }^{2}$ It is possible that pay for performance is even more widely utilized. If there are states with organizations using pay for performance but managers from those organizations were not in our sample, then utilization could exceed the level reported here.

${ }^{3}$ Only cases with valid observations on all variables in the model were included in the analysis.

${ }^{4}$ When considering this finding and the operationalization of this variable, one must bear in mind that more than $90 \%$ of the respondents have merit pay as part of their payfor-performance system. An examination of the six respondents in organizations using bonus systems and/or group-based approaches exclusively, reveals that two evaluated their system as effective, three did not consider their system to be effective, and one was uncertain.

${ }^{5} \mathrm{Many}$ of the same positive and negative outcomes examined here were previously examined with respect to pay for performance in local government in an insightful article by Streib and Nigro, 1993.

${ }^{6}$ These findings are particularly interesting since a considerably larger proportion of respondents ( 56.5 percent) had reported earlier that they considered their overall pay-forperformance system an effective tool for motivating employees and increasing productivity.

${ }^{7}$ A general reduction in turnover is, of course, not necessarily the result of a greater ability to retain top caliber employees, but the argument is that good employees will be more likely to be retained under pay for performance than poorer employees. At the same time, it could be argued that if merit pay led to increased turnover of lower quality employees, such an outcome would be beneficial. 
'Survey response categories for these items included strongly agree, agree, slightly agree, neither agree nor disagree, slightly disagree, disagree, and strongly disagree. Responses were scored from 1 (strongly agree) to 7 (strongly disagree). In Tables 2 and 3, this seven-point scale was collapsed into three categories. However, in calculating mean responses to each item the original seven-point scale was used.

\section{References}

Argyle, N. J. (1982). Civil service reform: The state and local response. Public Personnel Management, 11 (2), 157-164.

Daley, D. (1987). Merit pay enters with a whimper: The initial federal civil service reform experiences. Review of Public Personnel Administration, 7 (2), 72-79.

Dillman, D. A. (1978). Mail and telephone surveys: The totul destgn method. New York: John Wiley and Sons.

Fox, C. J. \& Miller, H. (1992). Symbolic politics as signature of the postmodern condition: Implications for personnel policy. Paper presented at the annual meeting of the American Political Science Association, Chicago, Illinois.

Gabris, G. T. (1986). Can merit pay system avoid creating discord between supervisors and subordinates? - another uneasy look at performance appraisal. Review of Public Personnel Administration, 7 (1), 70-89.

Ingraham, P. W. (1993a). Of pigs in pokes and policy diffusion: Another look at pay for performance. Public Administration Review, 53 (4), 348-356.

Ingraham, P. W. (1993b). Pay for performance in the states. American Review of Public Administration, 23 (3), 189-200.

Kellough, J. E. \& Lu, H. (1993). The paradox of merit pay in the public sector: Persistence of a problematic procedure. Review of Public Personnel Administration, 13 (2), 45-64.

Lawther, W. C. et al. (1989). Implications of salary structure and merit pay in the tifty American states. Review of Public Personnel Administration, 9 (2), 1-14.

Lovrich, N. P. (1987). Merit pay and motivation in the public workforce: Beyond technical concerns to more basic considerations. Review of Public Personnel Administration, 7 (2), 54-71.

Milkovich, G. T. \& Wigdor, A. K. (1991). Pay for performance: Evaluating Performance appraisal and merit pay. Washington D.C.: National Academy Press.

Nachmias, D. \& Moderacki, P. J. (1982). Patterns of support for merit pay and EEO performance: The inherent difficulties of implementing innovation. Policy Studies Journal, 11 (2), 318-327.

Pearce, J. L. \& Perry, J. L. (1983). Federal merit pay: A longitudinal analysis. Public Administration Review, 43, 315-325.

Pearce, J. L, Stevenson, W. B., \& Perry, J. L. (1985). Managerial compensation based on organizational performance: A time series analysis of the effects of merit pay. Academy of Management Joumal, 28 (2), 261. 278.

Perry, J. L. (1988-89). Making policy by trial and error: Merit pay in the federal service. Policy Studies Joumal, 17, 389-405.

Perry, J. L. \& Pearce, J. L. (1985). Civil service reform and the politics of performance appraisal. In David H. Rosenbloom (Ed.), Public personnel policy: The politics of civil service (pp. 146-158). Port Washington, NY: Associated Faculty Press.

Perry, J. L., Petrakis, B. A., \& Miller, T. K. (1989). Federal merit pay, round II: An analysis of the performance management and recognition system. Public Administration Review, 49 (1), 29-37.

Streib, G. \& Nigro, L. G. (1993). Pay for performance in local governments: Programmatic differences and perceived utility. Public Productivity and Management 
Review, 17(2), 145-159.

U.S. Federal Register. (1995). Performance management. 60 (18), 5542-5557.

U.S. General Accounting Office. (1990). Pay for performance: State and intemational public sector pay-for-performance systems. Washington, DC: Government Printing Office.
U. S. Statutes at Large. (1993). Performance Management and Recognition System Termination Act, Public Law 103-89, 107 Stat. 981.

\section{Call for Papers}

\section{The Impact of Privatization on Public Employees edited by Wendell C. Lawtier}

This symposium will examine the impact of privatization on public employees. The symposium will be blind refereed and will appear in Fall 1997.

Manuscripts are requested that examine all aspects of the privatization transfer process, including topics such as the tole of employees and unions in a privatization decision; the impact of the 1978 CSRA on federal agency decisions to privatize; employee rights and benefits identified in an RFP that seeks to privatize government services, and the impact of statelocal regulationsbumping tights - on the transition of a service from public to private.

Proposals for 20- to 25-page papers are welcome. Individuals are invited to submit a one page proposal with a tentative outline of their paper to:

\section{Wendell C. Lawther \\ Dept. of Public Administration \\ University of Central Florida \\ Orlando, FL 32816 \\ Tel: (407) 823-2604 \\ lawther@pegasus.cciucf.edu}

Proposals must be received no later than March 14, 1997.

Completed manuscripts are due by July 11, 1997. 